\section{THE CHEMICAL CONSTITUENTS' OF THE LEAVE ESSENTIAL OIL OF ALTERNANTHERA}

\section{PUNGENS (KUNTH)}

"Ogunmoye, Abdulrazaq Omotunde'; Atewolara-Odule, Odunayo Christy'; Olubomehin,

\section{Oseyemi Omowunmi'; Ogundare, Segun Ajibola' and Yussuf, Sodiq Tolulope}

'Department of Chemical Sciences, Olabisi Onabanjo University, P.M.B. 2002, Ago-Iwoye, Ogun State, Nigeria.

*Correspondent Author: e-mail omotunde.ogunmoye@oouagoiwoye.edu.ng

\section{ABSTRACT}

Alternanthera pungens Kunth commonly called khaki weed is from the family Amaranthaceae. It is a herbaceous perennial plant that has stems prostrate, rarely rising and about $10-50 \mathrm{~cm}$ long. The work was carried out due to the scarcity of information on the volatile constituents from the plant leaves despite works on the flower and other parts. The extraction of the essential oils from the dried leave was carried out by the hydro distillation method using an all-glass Clevenger apparatus. The extracted oils were then analyzed using gas chromatography-mass spectrometry (GC-MS). A total of twelve constituents' representing $93.39 \%$ of $A$. Pungens oil with a yield of $0.4 \%$ (v/w) was obtained. The analysis of the GC-MS rsults of the leaf oil showed that it was dominated by $\beta$-ionone $(42.18 \%)$ and octadecyne (4.72\%), undecane $(3.73 \%)$, para-mentha-1, 3, 8-triene (3.65\%), isophytol (3.21\%),

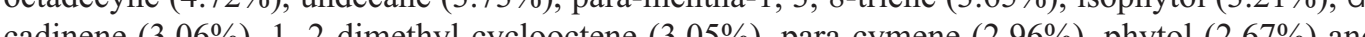
neophytadiene $(2.50 \%)$. The common classes of compounds present in the leaves oil are aceto monocyclic monoternenoid $(42.18 \%)$, sesquiterpenoids $(18.59 \%)$, hydrocarbons $(11.50 \%)$ diterpenoids $(8.38 \%)$, monoterpenes $(6.61 \%)$ and fatty acids $(6.13 \%)$. The constituents and the compositional pattern of essential oil identified from the leaves of Alternanthera pungens grown in Nigeria differ quantitatively and qualitatively from previously reported member of the genus and the presence of sesquiterpenoid as one of the major components of the oils justify the traditional use of the plants in treating pains, headaches and inflammations.

Keywords: Alternanthera pungens, Essential oil, $\beta$-iononeand Hexahydrofarnesyl acetone. Accepted Date: 16 June 2020

\section{INTRODUCTION}

The genus Alternanthera contains medicinal plants that possess volatile constituents, essential amino acids, flavonoids, glycosides and steroids (Khatun et al. 2012). Alternanthera pungens Kunth commonly known as khaki weed in English and 'dágunró 'in Yoruba Southwest Nigeria belongs to the Amaranthaceae family. It grows widely in tropical and subtropical regions throughout the world (Burkill, 1985). It is an herbaceous perennial plant that has stems prostrate, rarely rising and about 10-50 cm long (Marchant et al., 1987; Naidu, 2012; Hossain et al., 2018). Alternanthera pungens is reported to be used traditionally for the treatment of naso-pharyngeal infections, diarrhea, dysentery, vermifuges, dropsy, swellings, oedema, gout and venereal diseases (Zongo et al. 2011; Hundiwale et al. 2012). It is also use as a painkiller, for treating stomachache, swelling and for lactation stimulus in

veterinary (Burkill, 1985; Mourya et al., 2018). The plant has been shown to exhibit antioxidant, antimicrobial, antidiabetic, antidiarrhea, spasmogenic, diuretic, and anti-HIV properties (Petrusand Seetharaman, 2005). The analgesic potential of Alternanthera pungens ethat . analgesic effect compared to the standard used. The analgesic effect was attributed to the presence of phytochemicals like flavonoids, tannins an phenolic compounds (Hossain et al., 2018) Furthermore, phytochemicals such as; saponins, alkaloids, steroids, triterpenoids, leucoanthocyanidins, $\beta$-spinasterol, saponin sheteroside of oleanolic acid, glycosides, flavonoid stannins, carbohydrate, $\beta$-carotene, lutein, violaxanthin, zeaxanthin and choline has been (Gupta and Saxena, 1987; Mourya et al., 2018).
Occasionally, other genus like $A$. sessilis, $A$. philoxeroides, A. bettizicikiana and A. brasiliana (flowers, leaves, stems and roots extracts) have been reported to contain similar or related, but not necessarily the same chemical constituents in different percentages. Some of them includes; phaeophytina, $\beta$-sitosterol, $3 \beta$-hydroxystigmast -5 en-7-one, 24-methylene cycloartanol, cycloeuclenol, phytol, $\beta$-carotene, $\alpha$-spintanol, $\alpha$-spinasterol, triterpenoids, phytosterols, glycosides, alkaloids, flavonoids, steroids, phenolic compounds, carbohydrate, amino acids, proteins, ionone derivatives, saponins, lipids and tannins (De Sooza et al., 1998; Ragasa et al.,2002; Fang et al., 2006; Aguirre et al., 2013; Walter et al., 2014; Vidhya et al., 2015; Devi et al., 2015; Pulipati et al., 2016). The chemical compositions of essential oils (oxygenated sesquiterpenes, diterpenes ketones, fatty acid and esters) extracted from the flower and leaf of Alternanthera sessitis 作 y hydro distllation showed remarkable difference in constituents and percentage composition as well as difference in the antioxidant effect on 1diphenyl-2-picrylhydrazyl (DPPH) radical scavenging capacities. The major chemical composition of leaves oil are; 1, 1, 1, 5, 5, 5hexamethyl-3, 3-bis [(trimethylsilyl) oxy] trisiloxane $(15.43 \%)$ which is an oxygenated diterpenes followed by S, S-dioxide trans-2methyl-4-N-pentylthiane $(11.27 \%)$ didodecylp $(10.62 \%)$ and tetrahydro-2, didodecylphthalate $(10.62 \%)$ and tetrahydro-2, 5dimethoxy furan $(10.01 \%)$ while the prominent ones from flower oil are; $1,1,1,5,5,5$-hexamethyl3, 3-bis [(trimethylsilyl) oxy] trisiloxane (17.76\%), trans-4-ethyl-5-octyl-2, 2-bis (trifluromethyl)-1, 3dioxolane $(11.12 \%)$ and tetrahydro-2, 5-dimethoxy furan (9.10\%). (Khan et al.,2016). Similarly, A. triandra seed oil reported a moderate source of ricinoleic acid (22.1\%), myristic acid (3.9\%), palmitc acid $(16.9 \%)$, stearic acid $(5.90 \%)$, oleic paid $(26.0 \%)$ and linole acid $(25.2 \%)(\mathrm{Hos}$, oleic et al.2004). Although Alternanthera pungens flower has been analyzed Alternanthera pungens flower has been analyzed
with the following phytochemicals identified; $\alpha$ pinene $(7.40 \%), \beta$-pinene $(6.42 \%)$, camphene $(4.21 \%)$, myrecene $(3.61 \%)$, p-cymene $(4.29 \%)$ limonene (3.52\%), $\beta$-ocimene (2.35\%), 1,8-cineole (6.28\%), $\alpha$-thujone (3.62\%), $\alpha$-borneol (4.46\%), $\alpha$ curcumene $(2.36 \%)$, camphor $(5.52 \%)$, linalool $(6.29 \%)$, geraniol $(7.42 \%)$, $\alpha$-terpineol $(3.82 \%)$, elemol acetate (6.14\%), eudesmol (5.38\%), azulene $(3.16 \%)$ and three unidentified compound (Gupta and Saxena, 1987). However, there is paucity of information on the essential oil of the leaves. This research is therefore focused on the extraction and determination of the volatile constituents from the leaves of Alternanthera pungens.

\section{Materials and Methods}

\section{Plant materials}

Fresh leaves of Alternanthera pungens were obtained from a farm land within Olabisi Onabanjo University, Ago Iwoye, Ogun State, Nigeria. The sample was identified and authenticated at the herbarium of the Forestry Research Institute of Nigeria (FRIN) Ibadan by Mr. A. O. Adeyemo and a voucher specimen with herbarium number FHI110461 was deposited. The leaves were air dried at room temperature and pulverised before further study.

\section{Extraction of the leaf oi}

The air-dried pulverised leaves of Alternanthera pungens $(500 \mathrm{~g})$ was subjected to hydro distillation in a Clevenger-type glass apparatus for $3 \mathrm{~h}$ in accordance with established procedure (Ogundajo et al., 2016). The oils collected in hexane was preserved in anamber bottle and stored ina refrigerator for further analysis.

\section{Gas Chromatography-Mass Spectrometry}

\section{(GC/MS) of the leaf oil.}

The GC-MS analysis of the essential oil was carried out on an Agilent model 7890 A gas chromatograph equipped with a FID and fitted with a fused silica capillary HP-5MS column ( $30 \mathrm{~m} \times 0.32 \mathrm{~mm}$ id, film thickness $0.25 \mu \mathrm{m})$. The oven temperature was programmed from $80-240 \mathrm{oC}$ at the rate of $8 \mathrm{oC} / \mathrm{min}$. The ion source was put at $240 \mathrm{oC}$ while electron ionisation was set at $70 \mathrm{eV}$. Helium was used as the carrier gas at a flow rate of $2 \mathrm{~mL} /$ Scanning range was $35-425$ anu. Dited hexane $(1.0 \mu \mathrm{L})$ was injected into the GC/MS.

\section{Identification of the Leaf Essential Oi}

The identification of the constituents was performed on the basis of retention indices (RI) determined by co-injection with reference to a homologous series of n-alkanes, under identica experimental conditions. Further identification of the components was done by comparison of their 


\section{RESULTS}

mass spectra with those from NIST (Data base 69) and Wiley 9th Version and the home-made MS library composed of pure substances and components of known essential oils, as well as by comparing their retention indices with literature values (Adams, 2007; Aboaba et al., 2010).

The chemical constituents identified as revealed by GC-MS results as shows in (Fig. 1.0).Aceto monocyclic monoterpenoid (42.18\%), sesquiterpenoids $(18.59 \%)$, hydrocarbons $(11.50 \%)$, diterpenoids $(8.38 \%)$, monoterpenes $(6.61 \%)$ and fatty acids (6.13\%). However, sesterterpenes compounds were conspicuously

absent in the essential oil. The yield of essential oil was $0.4 \%(\mathrm{v} / \mathrm{w})$ calculated on a dry weight basis The oil sample was cloudy white in colour with strong herbal odour. A total of twelve constituents representing $93.39 \%$ of $\mathrm{A}$. pungens oil were identified. In addition, out of the constituents identified, $\beta$-Ionone has the highest percentage $(42.18 \%)$, followed by hexahy drofarnesyl acetone $(15.53 \%)$, others include; methyl palmitate $(3.73 \%)$, para-mect (3.73\%), para-mentha-1, 3,8 , 8 -triene $(3.65 \%)$ isophytol (3.21\%), -cadinene $(3.06 \%), 1,2-$ dimethyl cyclooctene $(3.05 \%)$, para-cymen $(2.96 \%)$, phytol $(2.67 \%)$ and neophytadien $(2.50 \%)$ with the lowest percentage (Table 1.0$)$.

TIC. ALPN D.DI clata.m

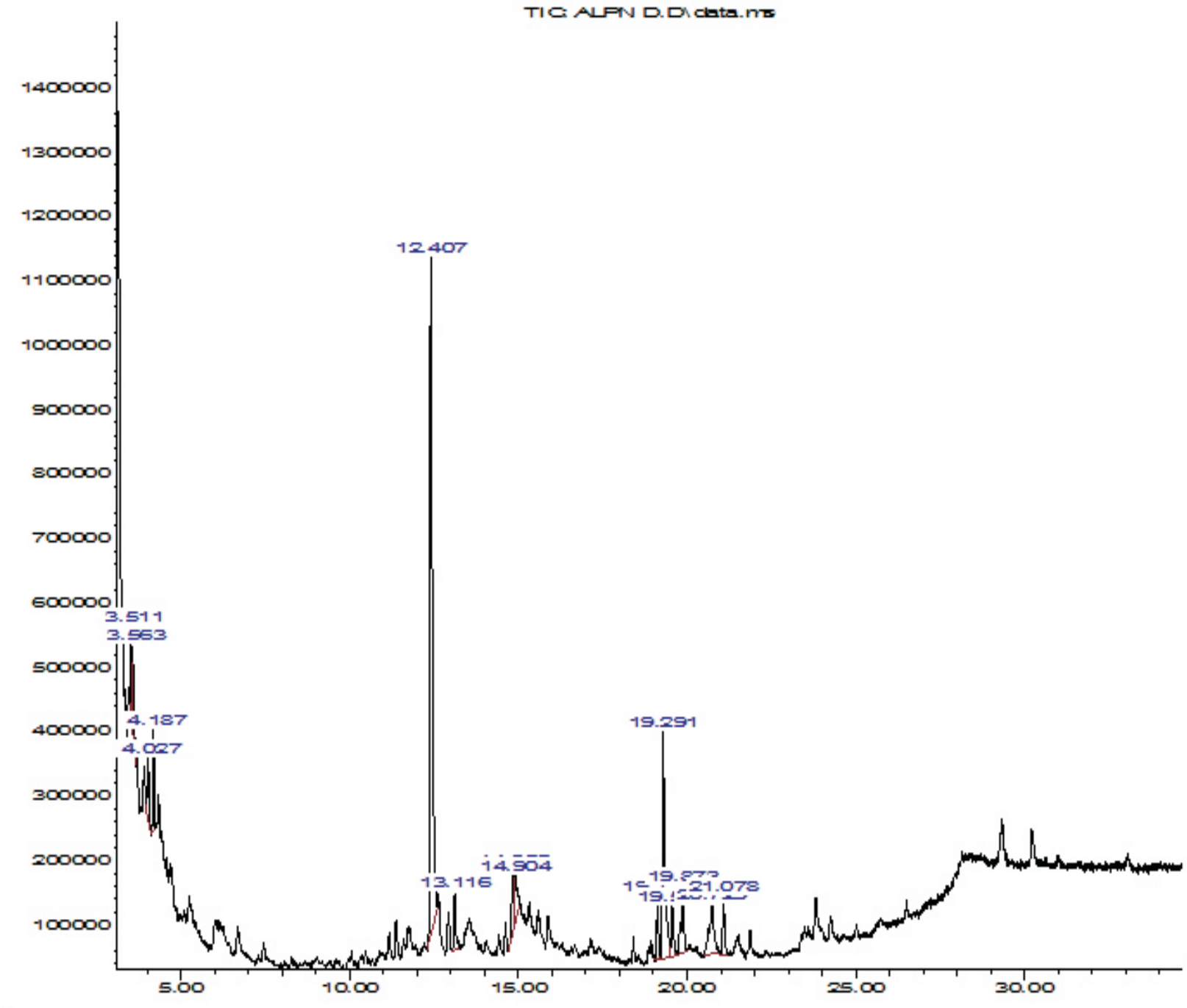

Fig. 1.0:Total Ion Chromatogram of leaf essential oil of A. pungens

P-ISSN 2536-6904, E-ISSN 2705-2761 African Journal of Science \& Nature Vol. 10, 131-136(2020)

Table 1.0: The chemical composition of the leaf essential oil of $A$. pungens

\begin{tabular}{|c|c|c|c|c|c|c|}
\hline $\mathrm{S} / \mathrm{N}$ & $\begin{array}{l}\text { Compounds } \\
\text { (common names) }\end{array}$ & $\begin{array}{l}\text { Retention } \\
\text { index cal }\end{array}$ & $\begin{array}{l}\text { Retention } \\
\text { index lit. }\end{array}$ & $\begin{array}{l}\text { Retention } \\
\text { time }\end{array}$ & $\begin{array}{l}\text { \% } \\
\text { Composition }\end{array}$ & $\begin{array}{l}\text { Molecular } \\
\text { formulae }\end{array}$ \\
\hline 1 & $\begin{array}{l}\text { 1,2-Dimethyl } \\
\text { cyclooctene }\end{array}$ & 986 & 990 & 3.511 & 3.05 & $\mathrm{C}_{10} \mathrm{H}_{18}$ \\
\hline 2 & $p$-Mentha-1,3,8-triene & 1000 & 1110 & 3.562 & 3.65 & $\mathrm{C}_{10} \mathrm{H}_{14}$ \\
\hline 3 & $p$-Cymene & 1074 & 1073 & 4.025 & 2.96 & $\mathrm{C}_{10} \mathrm{H}_{14}$ \\
\hline 4 & Undecane & 1115 & 1100 & 4.186 & 3.73 & $\mathrm{C}_{11} \mathrm{H}_{24}$ \\
\hline 5 & $\beta$-Ionone & 1468 & 1461 & 12.408 & 42.18 & $\mathrm{C}_{13} \mathrm{H}_{20} \mathrm{O}$ \\
\hline 6 & $\delta$-Cadinene & 1374 & 1530 & 13.118 & 3.06 & $\mathrm{C}_{15} \mathrm{H}_{24}$ \\
\hline 7 & Neophytadiene & 1810 & 1827 & 19.126 & 2.50 & $\mathrm{C}_{20} \mathrm{H}_{38}$ \\
\hline 8 & $\begin{array}{l}\text { Hexahydrofarnesyl } \\
\text { acetone }\end{array}$ & 1954 & 1858 & 19.292 & 15.53 & $\mathrm{C}_{18} \mathrm{H}_{36} \mathrm{O}$ \\
\hline 9 & Phytol & 2105 & 2111 & 19.566 & 2.67 & $\mathrm{C}_{20} \mathrm{H}_{40} \mathrm{O}$ \\
\hline 10 & 1-Octadecyne & 1920 & 1238 & 19.875 & 4.72 & $\mathrm{C}_{18} \mathrm{H}_{34}$ \\
\hline 11 & Methyl palmitate & 1942 & 1928 & 20.728 & 6.13 & $\mathrm{C}_{17} \mathrm{H}_{34} \mathrm{O}_{2}$ \\
\hline 12 & Isophytol & 1899 & 1920 & 21.077 & 3.21 & $\mathrm{C}_{20} \mathrm{H}_{40} \mathrm{O}$ \\
\hline
\end{tabular}

\section{DISCUSSIONS AND CONCLUSION}

The quantitative amount of $\beta$-ionone in this oil is noteworthy $(42.18 \%)$, since it has not been previously reported to be a major compound of $A$. pungens. $\beta$-Ionone is one of essential constituents in most aromatic oils used in the production of perfumes due to its strong pleasant odour (Cseke $e$ al., 2007). Furthermore, $\beta$-ionone has been reported to be fragrance ingredient in perfumery, cosmetics, personal care products, household cleaners and detergents. It is also a flavouring agent in beverages, baked goods, and candies $\beta$-ionone is of use, not only in perf of use, not only in perfunery, but also as a key interneding A, E and K (Lalko et al., 2007). Not suprisingly, the steam distillation of the flower essential oil $(0.6 \%)$ of $A$. pungens has a very different composition compared to the leaf oils. These includes; $\alpha$-pinene $(7.40 \%), \beta$-pinene $(6.42 \%)$, camphene $(4.21 \%)$, myrecene $(3.61 \%)$, para-cymene $(4.29 \%)$, limonene $(3.52 \%)$, $\beta$-ocimene $(2.35 \%)$, cineole (6.28\%) among others (Gupta and Saxena, 1987). Previous report on essentiat oils of another specie; revilis from . sessilis from components of leaves as $1,1,1,5,5,5$-hexamethyl3, 3 -bis [(time hylsilyl) oxy] trisiloxane $(15.43 \%)$ $\mathrm{S}, \mathrm{S}$ - dioxide trans - 2 - methy 1 - 4 - $N$ - penty 1 thiane $(11.27 \%)$, didodecylphthalate $(10.62 \%)$ and tetrahydro-2, 5-dimethoxy furan (10.01\%), unlike the current work that was majorly dominated by $\beta$ ionone $(42.18 \%)$ and hexahydrofarnesyl acetone $(15.53 \%)$. The other characteristics compounds previously reported from $A$ sessilis were; octy ester-2-propenoic aid $(9.32 \%)$, 1-fluorododecan (6.60\%), 1-chlorocidecane $(6.60 \%), 1$-che $O$-methyl- $\alpha$ - $D$-xylofuranoside (3.13\%), (Z)-7 tetradecene $(3.12 \%)$, trimethyl (4terbutylphenoxy) silane (2.98\%), 1,1'-oxybisheptane $(2.41 \%)$, cis-4-penty 1-5-propyl-2, 2-bis (trifluoromethyl)-1, 3-dioxane (2.29\%) and 9heptadecanone (2.06\%) (Khan et al., 2016).

The chemical compositions of essential oil from the leaves of $A$. pungens grown in Nigeria are being reported for the first time based on available information. The ar il from $A$. pungens showed the prential oil from $A$. pungens showed the presence of acet monocyclic monoterpenoids (42.18\%), sesquiterpenoids (21.41\%) and hydrocarbons $(11.50 \%)$ as the major predominant classes of compounds. Oxygenated diterpenes (11.27\%) was reported as the most prominent from the leaf oil of A. sessilis (Khan et al., 2016) as compared to aceto monocyclic monoterpenoids (42.18\%) which is the major class in the present study. It was observed 
essential oil from the leaves of Alternanthera pungens grown in Nigeria differ quantitatively and ualitatively from previously reported member of the genus (Khan et al., 2016). This may be attributable to factors such as the ecological and climatic conditions as well nature and age of the plant, period of collection, handling procedures and other related factors known to induce variation in essential oil composition extracted from plants (Gut Inikpi et al. 2014; Rehman et al, 2016; Ibanez and Blazquez, 2019). Conclusively, the chemical compositions of essential oil from the leaves of $A$. pungens grown in Nigeria are being reported for the first time based on available information. The presence of sesquiterpenoid as one of the major classes of compounds of the oils justifies the traditional use of the plants in treating pains, headaches and inflammations. Also, the identified chemical constituents of the plant are an addition to the chemical data base for the plant.

\section{Acknowledgments}

Authors are grateful to Miss. Hammed, Rashidat Oluwakemi for the assistance in the extraction of the oil sample.

\section{References}

Aboaba, S. A., Aiyelaagbe, O. O. and Ekundayo, O. O. (2010). Chemical Composition, Toxicity and Larvicidal Activity of the Essential Oil from the Whole Plant of Acalypha segetalis from South-West Nigeria. Natural Product Communications, 5(3): 481- 483.

Adams, R. P. (2007).Identification of Essential Oil Components by Gas Chromatography/Mass Spectrometry (4th edition), Allured Publishing Corp., Carol Stream, IL, USA.

Aguirre, A., Borneo, R. and Le'on A. E. (2013). Antimicrobial, mechanical and barrier properties of triticale protein films incorporated with oregano essential oil. Food Bioscience, 1: $2-9$.

Burkill, H. M. (1985). The useful plants of west tropical Africa. Royal Botanic Gardens, Kew, UK. 3 .

Cseke, L. J., Kaufman, P. B., and Kirakosyan, A. (2007). The biology of essential oils in the pollination of flowers. Natural Product
Communications, 2 (12):1317-1336

M. M., Ana, P. K., Floriani, E. O. an Cechinel-Filho, V.(1998). Analgesi Properties of a Hydroalcoholic Extract Obtained from Alternanthera brasiliana. Phytotherapy Research, 12:279-281

Devi, A. D., Singh, T. C., Devi, O. I., Singh, S. S Singh, A. R. and Singh, E. J. (2015) Phytochemical Analysis of Some Traditiona Aromatic Plant Species of Thoubal District, Manipur. Asian Journal of Pharmaceutical Science and Technology, 5(1): 50-53.

Fang, J. B., Duan, H. Q., Zhang, Y. W. And Yoshihisa, T. (2006). Chemical constituents from herb of Alternanthera philoxeroides. China Journal of Chinese Material Medica,31(13): 1072-1075.

Gupta, R. K. and Saxena, V. K. (1987). Volatile constituents from the flowers of Alternamthera constituents from the Perfume, 31(4): 366-369.

Gurusaravanan, P., Pandiyarajan, V. and Jayabalan, N.(2010). Effect of the seaweed liquid fertilize on growth and productivity of Vignaradiat L.) Wilczek. Green Farm, 1(2): 138-140.

Hosamani, K. M., Ganjihal, S. S. and Chavadi, D. V. (2004). Alternanthera triandra seed oil: A moderate source of ricinoleic acid and its possible industrial utilization. Industrial Crop s and Products, 19: 133-136.

Hossain M. D. S., Rana, M. D. S., Rajibul Islam, Mahmudul Islam, A.F. M. (2018). Phenolic content analysis and evaluation of antinociceptive, antioxidant, antiinflammatory potential of Alternanthera pungens KUNTH. Journal of Bangladesh pungens KUNTH. Journal of Bang

Academy of Sciences, 42 (2): 129-136
Hundiwale, J. C., Patil, A. V., Kulkarni, M. V., Patil, D.A. and Mali, R. G. (2012). A current update on phytopharmacology of the genus Alternanthera. Journal of Pharmacy Research 5(4): 1924-1929.

Ibanez, M. D. and Blazquez, M. A. (2019). Essential Oils: Quality Indicators of Spices in Supermarkets. Nereis. Interdisciplinary IberoAmerican Journal of Methods, Modelling and Simulation Marzo, 11:39-50

Inikpi, E., Lawal, O. A., Ogunmoye, A. O. and Ogunwande, I. A. (2014). Volatile composition of the floral essential oil of Hibiscus sabdariff L. from Nigeria. America Journal of Essential
Oils and Natural Products, 2 (2): 4-7.

D., Koeng, W. A and Verlag, E.B, Hamburg. 1998 (1999). The Atlas of Spectra Data of Sesquiterpene Hydrocarbons. Journal of Natural Product, 62 (8): 1212-1213.

Khan, M. S., Yusufzai, S. K., Kaun, L. P., Shah, M. D. and Idris, R. (2016). Chemical composition and antioxidant activity of essential oil of leaves and flowers of Alternanthera sessilis red from Sabah. Journal of Applied Pharmaceutical Science, 6(12): 157-161

Khatun, F., Zaman, F., Mosaiab, T., Mostafa, F., Zaman, M., Rehana, F., Nasrin, D., Jamal, F., Nahar, N. and Rahmatullah, M. (2012). Evaluation of antinociceptive and antihyperglycemic activities in methanol extracts of whole plants of Alternanthera philoxeroides (Mart.) Griseb. (Amaranthaceae) in mice. Parkistan Journal of Pharmaceutical Sciences, 25: 583-587

Lalko, J., Lapczynski, A., McGinty, D., Bhatia, S., Letizia, C. S. and Api, A. M. (2007) Fragrance material review on trans-beta-ionone. Food and Chemical Toxicology, 45(1): 248-50.

Marchant, N.G., Wheeler, J.R., Rye, B.L., Bennett, E.M., Lander, N.S. and Macfarlane, T.D. (1987). Flora of the Perth Region. (Western Australian Herbarium, Department of Agriculture, Western Australia). p92.

Mourya, P., Singh, G., Jain, N., Gupta, M. K. (2018) In-vitrostudies on inhibition of alpha amylase and alpha glucosidase by plant extracts of Alternanthera pungens KUNTH. Journal of Drug Delivery \& Therapeutics, 8 (6-A): 64-68

Naidu, V. S. G. R. (2012). Hand Book on Weed Identification Directorate of Weed Science Research, Jabalpur, India. p. 354

Ogundajo, A. L., Nnaemeka, C. O., Olawunmi, R. O. and Ogunwande, I. A. (2016). Chemical Constituents of Essential oil of Ethretia cymosa Thonn. British Journal of Applied science and Technology, 14 (4): 1-6

Petrus, A. J. A. and Seetharaman, T. R. (2005). Antioxidant flavone C-biosides from the aerial parts of Alternanthera pungens. Indian Journal of Pharmaceutical Sciences, 67 (2): 187-193.

Pulipati, S., Srinivasa, B. P., Sree, N. B., Kumar, U. E., Shaheela, S., Krishna, J. M. and Chakradhar, T. (2016). Phytochemical Analysis and Antimicrobial Investigations of Ethanolic Leaf Extract of Alternanthera philoxeroides (MART.) GRISEB. World Journal of Pharmacy and Pharmaceutical Sciences, 5 (2): 1122-1129.

Ragasa, C. Y., Tremor, N. and Rideout, J. A. (2002) Ionone derivatives from Alternanthera sessilis. Journal of Asian Natural Products Research,4 (2): 109-115.

Rehman, R., Hanif, M. A., Mushtaq, Z. and Al-Sadi, A.M.(2016). Biosynthesis of essential oils in aromatic plants: a review. Food Reviews International,32 (2): 117-160

Verma, R.S., Padalia, R. C. and Chauhan, A.(2013) Introduction of Cymbopogondistans (Nees ex Steud.) Wats to the sub-tropical India: evaluation of essential-oil yield and chemical composition during annual growth. Industrial Crops and Product, 49: 858-863.

Vidhya, T., Suji, T., Dhatchayani, R., Priya, C. L. and Bhaskara-Rao, K. V. (2015). Evaluation of In-vitro Antioxidant, Antimicrobial Activities and GC-MS Analysis of Alternanthera bettizicikiana Linn. Leaf Extracts. International Journal of Pharmacognosy and Phytochemical Research, 7 (6): 1072-1079

Walter, T. M., Merish, S. and Tamizhamuthu, M. (2014). Review of Alternanther asessilis with Reference to Traditional Siddha Medicine. International Journal of Pharmacognosy and Phytochemical Research, 6 (2): 249-254

Zongo, C., Savadogo, A., Somda, M. K., Koudou, J. and Traore, A. S. (2011). In vitro evaluation of the antimicrobial and antioxidant properties of extracts from whole plant of Alternanthera pungens H.B. \& K. and leaves of Combretum sericeum G. Don. International Journal of Phytomedicine, 3: 182-191 